\title{
Characterization and Profiling of Industrial Wastewater Toxicity in Kuwait
}

\author{
Mohd Elmuntasir Ahmed, Adel Al-Haddad, and Suad Al-Dufaileej
}

\begin{abstract}
Toxicity reduction is a main criterion in prioritizing industrial wastewater treatment objectives. This paper utilized a comprehensive survey of $\mathbf{4 1}$ industrial facilities to characterize their wastewater quality parameters and to assess their wastewater toxicity. The 41 factories were grouped under eleven industrial categories. Microtox relative toxicity test results indicated that industrial wastewater in Kuwait are mostly very toxic to toxic with the exception of farms wastewater which was found to be slightly toxic. The highest ranking toxic wastewaters where found to be metal forming, printing, dairy, slaughterhouses, petrochemical, poultry, food, paper and packaging, beverage, and construction materials industries in order. Among the contributing factors to the toxicity of industrial wastewater are temperature, $\mathrm{pH}$, metals, COD, TOC, NH3, TPH, phenol, and BTEX.
\end{abstract}

Index Terms-Industrial wastewater, Microtox, pollution, toxicity.

\section{INTRODUCTION}

Fast paced industrialization and the complexity of the industrial supply chain increases the production of industrial wastewater which contains highly toxic components. Depending on the type of industry, the industrial wastewater may contain variable levels of toxic compounds [1]. Industrial wastewater is one of the major environmental pollution sources among all sources [2], it contains a mixture of chemical compounds, which are used during industrial processing which are not usually degradable using conventional treatment and have adverse impacts on the environmental health [3]-[12]. Moreover, industrial wastewater causes severe toxic effects in aquatic ecosystems [13].

Industrial wastewater is often depleted in dissolved oxygen due to its high organic content and, thus, encourages anaerobic/anoxic conditions, leading to odour problems [14]-[16]. Also, the elevated concentration of heavy metals may cause low quality water when discharged to water bodies and cause contamination of agricultural soils [17]. However, the heavy metal toxicity depends to a great extent on its chemical speciation and thus, the associated health effects are influenced by the chemical forms of exposure [18].

The presence of pathogens in Industrial wastewater has

Manuscript received August 29, 2021; revised September 28, 2021. This work was supported in part by the Kuwait Foundation for the Advancement of Sciences (KFAS) under Grant \# P316-25EC-01 and the Kuwait Institute for Scientific Research (KISR) under Grant \# WT036C.

Mohd Elmuntasir Ahmed, Adel Al-Haddad, and Suad Al-Dufaileej are with Kuwait Institute for Scientific Research, Kuwait City, Kuwait (e-mail: miahmed@kisr.edu.kw, ahadad@kisr.edu.kw, sleej@kisr.edu.kw). been documented and reviewed by many [12], [19]. Since industrial wastewater is rich in organic and inorganic constituents it may provide a chance to a variety of pathogenic bacteria to flourish as these constituents may act as a source of nutrients [16], [19].

Typically, wastewater analysis includes certain physico-chemical, biological, and organic analysis [1] based on legal obligations. Due to advances in analytical chemistry, increasingly more pollutants can be identified and quantified at very low concentrations [13]. This routine chemical analyses do not take into account the toxic effects of wastewater [1]. Recently, more attention is paid to the toxicity evaluation for industrial raw and treated effluents due to the imposition of stringent laws on discharge standards [20]-[22].

This paper investigates the common pollutants found in eleven industrial categories in Kuwait and their corresponding toxicity. This knowledge is important to further the abatement and management of the negative impacts of industrial wastewater [23].

\section{METHODOLOGY}

Agreement of the owners of 41 factories out of 75 contacted was obtained to participate in this study. The locations and coding of 14, 10, and 17 factories from three industrial areas (Fig. 1) are shown in Fig. 2-4. The 41 factories were grouped into 11 groups based on the type of industry as shown in Table I.

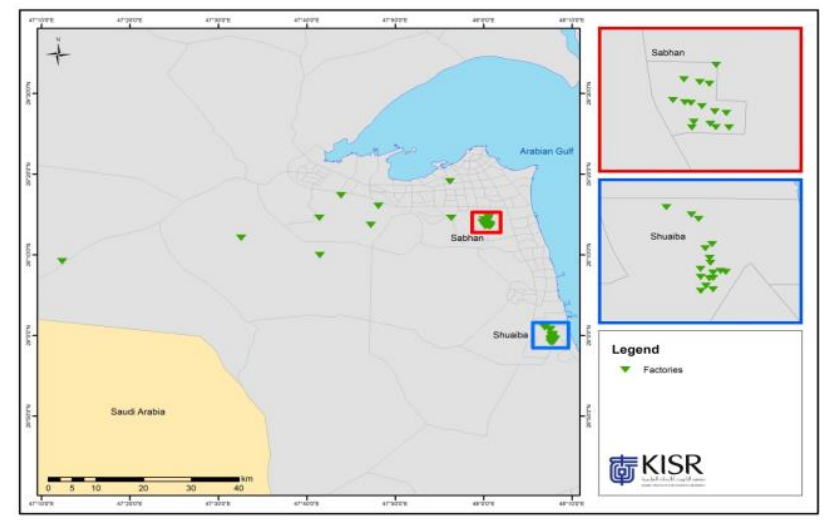

Fig. 1. Location map of selected factories in three industrial areas of Kuwait

The measurements and sampling started for all factories in mid-December 2018 on a biweekly basis except for factories in Sabhan industrial area where the sampling started on a monthly basis during the period between mid-December 2018 and end of April 2019, as instructed by the owners of factories, followed by biweekly sampling during June -July 2019. The wastewater sampling was stopped during May 
2019, resumed in June 2019, and was completed by the end of July 2019. Also, wastewater was not collected, especially when the wastewater collection points were dry during the visit of the field team to the factory.

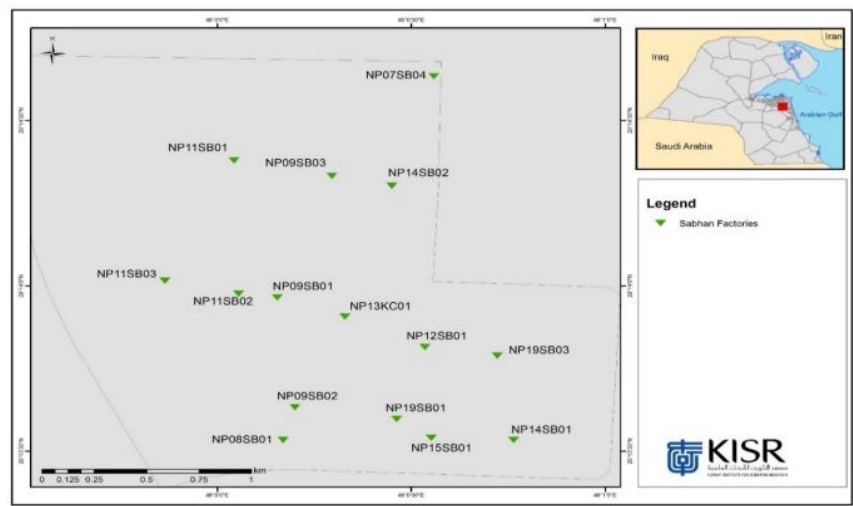

Fig. 2. Location map of selected factories at Sabhan industrial area.

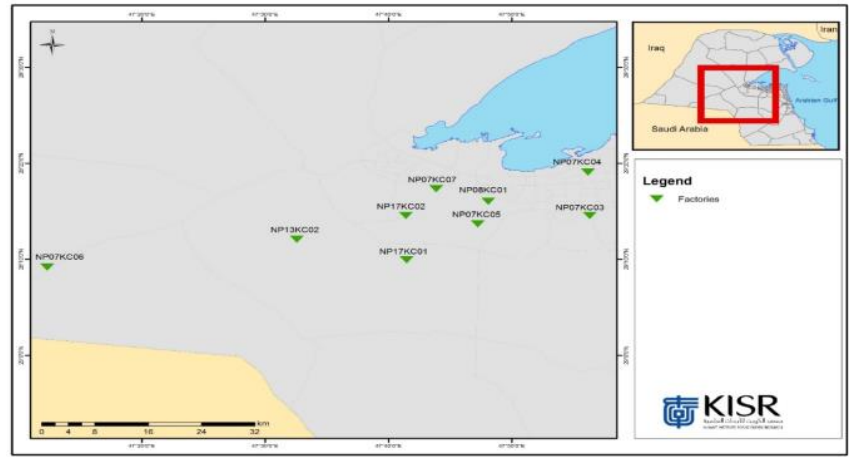

Fig. 3. Location map of selected factories and sites at Kuwait city.

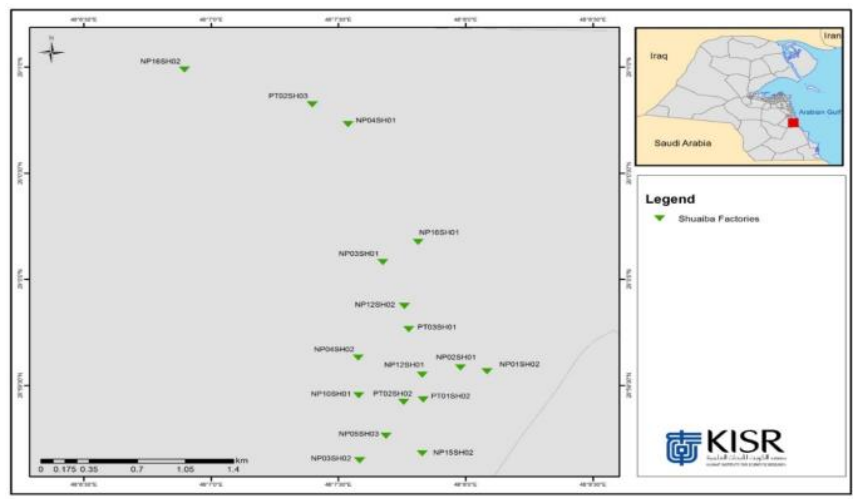

Fig. 4. Location map of selected factories at Shuaiba industrial area.

The analysed parameters consisted of temperature, $\mathrm{pH}$, electrical conductivity (EC), dissolved oxygen (DO), and oxidation reduction potential (ORP), total suspended solids (TSS), total dissolved solids (TDS), total phosphate (T.PO ${ }_{4}^{-}$), ammonia $\left(\mathrm{NH}_{3}\right)$, total Kjeldahl nitrogen $(\mathrm{TKN})$, total nitrogen $(\mathrm{TN})$, sulphide $\left(\mathrm{S}^{-2}\right)$, free chlorine $\left(\mathrm{F}^{\left.-\mathrm{Cl}_{2}\right)}\right.$, floatables, fluoride $(\mathrm{F})$, chemical oxygen demand (COD), biochemical oxygen demand (BOD), total organic carbon (TOC), oil and grease $(\mathrm{O} \& \mathrm{G})$, total petroleum hydrocarbon $(\mathrm{TPH})$, phenol, benzene, toluene, ethylbenzene, and xylene, Aluminium (Al), Arsenic (As), Barium (Ba), Boron (B), Cadmium (Cd), Cobalt $(\mathrm{Co})$, Chromium $(\mathrm{Cr})$, Copper $(\mathrm{Cu})$, Iron $(\mathrm{Fe})$, Mercury (Hg), Manganese (Mn), Nickel (Ni), Lead (Pb), Antimony ( $\mathrm{Sb}$ ), and Zinc (Zn). Finally, total coliform (TC), faecal coliform (FC), E. coli, enterococci, Salmonella bacteria, fungi, coliphage virus, parasites, and relative toxicity. Surfactants were analysed only for two detergent factories in Sabhan Industrial area.

TABLE I: CATEGORIES AND CODES OF DIFFERENT FACTORIES

\begin{tabular}{|c|c|c|c|}
\hline Sl .No. & Category of Industry & Number of Factories & Codes \\
\hline 1 & Food & 8 & $\begin{array}{l}\text { NP07-SB04 } \\
\text { NP08-SB01 } \\
\text { NP09-SB01 } \\
\text { NP09-SB02 } \\
\text { NP09-SB03 } \\
\text { NP19-SB01 } \\
\text { NP19-SB03 } \\
\text { NP07KC04 }\end{array}$ \\
\hline 2 & Beverage & 3 & $\begin{array}{l}\text { NP11-SB01 } \\
\text { NP11-SB02 } \\
\text { NP11-SB03 }\end{array}$ \\
\hline
\end{tabular}

NP17KC02

5 Dairy 11 NP08KC01

6 Poultry 2 NP07KC06

NP07KC07

$7 \quad$ Slaughterhouses $\quad 2 \quad$ NP07KC05

$\mathrm{NP} 07 \mathrm{KCO}$

$8 \quad$ Petrochemical

NP10-SH01

PT03-SH01

PT01-SH02

PT02-SH02

PT02-SH03

9

Metal forming

NP05-SH03

NP15-SB01

10

Paper and packaging

NP12-SH01

NP12-SH02

NP12-SB01

NP15-SH02

11 construction materials

10

NP14-SB01

NP14-SB02

NP03-SH01

$\mathrm{NP03}-\mathrm{SH} 02$

NP16-SH01

NP02-SH01

NP01-SH02

NP04-SH01

NP04-SH02

NP16-SH02

In general, with the exception of surfactants, the 45 wastewater parameters were analysed for 41 factories distributed in three industrial areas on a biweekly basis for seven months' period. The wastewater field measurements, sampling, and laboratory analysis activities were carried out according to the Standard Method for Water and Wastewater Examination, American Public Health Association [24].

Relative toxicity was measured using Microtox rapid toxicity test because of its sensitivity and high reproducibility [25]. The relative toxicity of the industrial wastewater 
samples was assessed by employing Microtox Assay System (Model 5000) with Microtox data collection and reduction software (Microtox Omni ${ }^{\mathrm{TM}}$, Microbics Corporation, Carlsbad, CA, USA). No adjustments to sample $\mathrm{pH}$ or other constituents were made. The assay was carried out according to the instructions of the manufacturer. Microtox reagent (freeze dried bacteria Aliivibriofischeri) was reconstituted in $1 \mathrm{ml}$ ultra-pure water reagent (Azur Environmental (SDI). The industrial wastewater samples $(2.5 \mathrm{ml})$ and $0.25 \mathrm{ml}$ osmotic solutions were mixed separately. This mixture was diluted serially in 4 separate cuvettes. The temperature was allowed to equilibrate for $5 \mathrm{~min}$ and the reagent was added to each of the cuvette, mixed thoroughly and allowed to stabilize for $15 \mathrm{~min}$. Each cuvette was then read on the Microtox analyzer. The lyophilized Aliivibriofischeri bacteria were obtained from Azur Environmental (AZF686018A). All aspects of testing were performed following the U.S. EPA guidelines [26]-[29].

\section{RESUlTS AND DISCUSSION}

\section{A. Industrial Wastewater Characteristics}

The results of the wastewater quality parameters are given in Table II through Table IV by category of industry type. Table II reveals that most industrial wastewaters are $\mathrm{pH}$ neutral ( $\mathrm{pH}$ 6-8) with the exception of construction materials, petrochemical, and printing industries which are more basic. With respect to the DO, the poultry, printing, and slaughterhouses wastewater is depleted. The food industry contains the highest amount of TSS and the petrochemical industry has the highest TDS. The EC is the highest in the printing and packaging industry. In none of the industries $\mathrm{H}_{2} \mathrm{~S}$ gas was detected.

Table III shows the nutrient averages by industry type. The highest ammonia corresponds to the highest TKN and TN indicating that significant portion of the total nitrogen is ammonia. Total phosphorous was detected at higher levels in the food industry.

TABLE II: PHYSICOCHEMICAL PARAMETERS OF INDUSTRIAL WASTEWATER (MG/L)

\begin{tabular}{|c|c|c|c|c|c|c|c|}
\hline Industry type & Temperature & $\mathrm{pH}$ & DO & \multicolumn{2}{|c|}{$\mathrm{EC}$} & TDS & TSS \\
\hline Beverage & $29.4 \pm 0.9$ & $5.7 \pm 0.1$ & $0.0 \pm 0.0$ & \multicolumn{2}{|c|}{$0.4 \pm 0.0$} & $158.6 \pm 23.1$ & $48.2 \pm 3.2$ \\
\hline Construction materials & $30.20 \pm .9$ & $8.6 \pm 0.1$ & $3.8 \pm 0.2$ & \multicolumn{2}{|c|}{$3.7 \pm 0.5$} & $905.8 \pm 74.3$ & $312.2 \pm 68.3$ \\
\hline Dairy & $25.1 \pm 1.0$ & $6.6 \pm 0.1$ & $4.8 \pm 0.1$ & \multicolumn{2}{|c|}{$0.8 \pm 0.2$} & $48.4 \pm 2.6$ & $53.1 \pm 2.7$ \\
\hline Farms & $25.1 \pm 1.0$ & $7.4 \pm 0.1$ & $4.8 \pm 0.2$ & \multicolumn{2}{|c|}{$0.3 \pm 0.0$} & $66.1 \pm 9.4$ & $16.0 \pm 1.8$ \\
\hline Food & $27.0 \pm 0.8$ & $6.8 \pm 0.1$ & $0.9 \pm 0.1$ & \multicolumn{2}{|c|}{$1.3 \pm 0.2$} & $106.8 \pm 15.0$ & $43587.5 \pm 16.0$ \\
\hline Metal forming & $37.7 \pm 2.5$ & $7.9 \pm 0.3$ & $2.3 \pm 0.4$ & \multicolumn{2}{|c|}{$2.3 \pm 0.4$} & $921.1 \pm 139.3$ & $15.6 \pm 2.1$ \\
\hline Paper and packaging & $32.8 \pm 1.2$ & $7.0 \pm 0.1$ & $0.8 \pm 0.1$ & \multicolumn{2}{|c|}{$6.2 \pm 0.7$} & $3978.1 \pm 522.9$ & $636.7 \pm 70.1$ \\
\hline Petrochemical & $26.6 \pm 0.8$ & $8.2 \pm 0.1$ & $1.3 \pm 0.2$ & \multirow{2}{*}{\multicolumn{2}{|c|}{$\begin{array}{l}4.1 \pm 0.7 \\
2.2 \pm 0.2\end{array}$}} & $1844.3 \pm 233.2$ & $337.4 \pm 46.5$ \\
\hline Poultry & $25.4 \pm 0.9$ & $6.5 \pm 0.1$ & $0.0 \pm 0.0$ & & $2.2 \pm 0.2$ & $890.9 \pm 51.5$ & $367.6 \pm 37.5$ \\
\hline Printing & $23.9 \pm 0.7$ & $9.1 \pm 0.4$ & $0.0 \pm 0.0$ & \multicolumn{2}{|c|}{$10.9 \pm 2.0$} & $4987.6 \pm 917.7$ & $165.8 \pm 27.5$ \\
\hline Slaughterhouses & $25.0 \pm 0.9$ & $6.7 \pm 0.1$ & $0.0 \pm 0.0$ & \multicolumn{3}{|c|}{$1.7 \pm 0.1$} & $385.9 \pm 58.4$ \\
\hline \multicolumn{8}{|c|}{ TABLE III: NUTRIENTS CONTENT OF INDUSTRIAL WASTEWATER (MG/L) } \\
\hline Industry type & NH3 & \multicolumn{2}{|l|}{ TKN } & \multicolumn{3}{|c|}{$\begin{array}{c}\mathrm{TN} \\
\end{array}$} & $\mathrm{TP}$ \\
\hline Beverage & $7.1 \pm 1.3$ & $16.8 \pm 1.7$ & & & $21.9 \pm 1.8$ & & $0.3 \pm 0.1$ \\
\hline Construction materials & $2.2 \pm 0.2$ & $7.9 \pm 0.7$ & & & $18.1 \pm 1.8$ & & $0.5 \pm 0.1$ \\
\hline Dairy & $4.5 \pm 1.1$ & $26.2 \pm 2.1$ & & & $34.1 \pm 2.7$ & & $0.1 \pm 0.0$ \\
\hline Farms & $6.3 \pm 1.0$ & $9.7 \pm 1.4$ & & & $15.8 \pm 1.4$ & & $0.1 \pm 0.0$ \\
\hline Food & $20.9 \pm 1.8$ & $9.6 \pm 1.3$ & & & $18.7 \pm 2.6$ & & $22.3 \pm 1.7$ \\
\hline Metal forming & $2.9 \pm 0.7$ & $4.6 \pm 0.8$ & & & $11.8 \pm 2.2$ & & $0.1 \pm 0.0$ \\
\hline Paper and packaging & $8.3 \pm 1.5$ & $21.9 \pm 2.3$ & & & $29.9 \pm 2.5$ & & $0.5 \pm 0.1$ \\
\hline Petrochemical & $10.0 \pm 1.7$ & $16.7 \pm 1.7$ & & & $23.2 \pm 2.2$ & & $0.3 \pm 0.0$ \\
\hline Poultry & $20.1 \pm 3.6$ & $314.5 \pm 49$ & & & $318.5 \pm 49.8$ & & $0.6 \pm 0.1$ \\
\hline Printing & $10.3 \pm 1.6$ & $28.9 \pm 5.7$ & & & $27.3 \pm 2.5$ & & $0.5 \pm 0.2$ \\
\hline Slaughterhouses & $15.1 \pm 1.8$ & $56.2 \pm 24.3$ & & & $96.4 \pm 22.3$ & & $0.7 \pm 0.1$ \\
\hline & TABLE IV: O & S CONALTH OT & IDUSTRI & & TER (MG/L) & & \\
\hline Industry type & O.\&G. & BOD & & & TOC & $\mathrm{TPH}$ & Phenol \\
\hline Beverage & $6.3 \pm 0.8$ & $870.7 \pm 42.3$ & 121 & 2.1 & $31.5 \pm 3.8$ & $4.3 \pm 0.8$ & $0.1 \pm 0.0$ \\
\hline construction materials & $8.6 \pm 0.7$ & $148.6 \pm 14.6$ & 238 & 3.3 & $72.7 \pm 7.7$ & $8.8 \pm 0.7$ & $0.1 \pm 0.0$ \\
\hline Dairy & $18.0 \pm 1.8$ & $58.0 \pm 2.5$ & & & $26.1 \pm 2.1$ & $5.5 \pm 1.3$ & $0.1 \pm 0.0$ \\
\hline Farms & $1.3 \pm 0.1$ & $12.2 \pm 1.7$ & & & $7.0 \pm 0.9$ & $1.0 \pm 0.0$ & $0.0 \pm 0.0$ \\
\hline Food & $43598.7 \pm 16.3$ & $374.7 \pm 24.3$ & & & $14.7 \pm 1.3$ & $5.8 \pm 1.5$ & $3.5 \pm 0.5$ \\
\hline Metal forming & $2.5 \pm 0.5$ & $32.1 \pm 2.1$ & & & $19.3 \pm 2.7$ & $2.0 \pm 0.0$ & $0.1 \pm 0.0$ \\
\hline Paper and packaging & $9.7 \pm 1.2$ & $936.8 \pm 125.3$ & 1505 & 84.4 & $118.6 \pm 14.3$ & $3.2 \pm 0.7$ & $0.3 \pm 0.0$ \\
\hline Petrochemical & $19.7 \pm 1.7$ & $1002.6 \pm 150.2$ & 1975 & 12.7 & $81.1 \pm 10.2$ & $12.8 \pm 1.2$ & $0.1 \pm 0.0$ \\
\hline Poultry & $25.8 \pm 2.1$ & $1922.1 \pm 86.5$ & 3388 & 73.8 & $31.3 \pm 2.1$ & $3.8 \pm 0.5$ & $0.1 \pm 0.0$ \\
\hline Printing & $3.2 \pm 0.6$ & $190.1 \pm 39.4$ & 298 & 1.0 & $13.3 \pm 1.8$ & $1.4 \pm 0.3$ & $0.1 \pm 0.0$ \\
\hline Slaughterhouses & $14.1 \pm 2.0$ & $562.9 \pm 187.3$ & 926. & 4.9 & $22.5 \pm 1.9$ & $2.9 \pm 0.4$ & $0.1 \pm 0.0$ \\
\hline
\end{tabular}

From Table IV, O\&G is the highest in the food industry as expected while BOD and COD are highest in the poultry and petrochemical industry. The TOC was highest in the paper and packaging industry, TPH was highest in the petrochemical industry as expected and was present at elevated levels in the construction materials industry.
However, the highest level of phenol was recorded in the food industry probably due to decay of organic compounds in wastewater. Surfactants were only detected in the food industry with average concentrations of $0.35 \pm 0.1 \mathrm{mg} / \mathrm{l}$ which could be attributed to use of excessive cleaning chemicals.

It is worth noting that BTEXs have only been detected in 
the petrochemical industry at average values of $0.04 \pm 0.01$, $0.11 \pm 0.03,0.03 \pm 0.01,0.09 \pm 0.03 \mathrm{mg} / \mathrm{l}$ for benzene, toluene, ethylbenzene, and xylene, respectively.

Metal toxicity is of great environmental concern because of their bioaccumulation and nonbiodegradability in nature (Igiri et al., 2018). Several inorganic metals like magnesium $(\mathrm{Mg})$, nickel $(\mathrm{Ni})$, chromium $\left(\mathrm{Cr}^{3+}\right)$, copper $(\mathrm{Cu})$, calcium $(\mathrm{Ca})$, manganese $(\mathrm{Mn})$, and sodium $(\mathrm{Na})$ as well as zinc $(\mathrm{Zn})$ are vital elements needed in small quantity for metabolic and redox functions. Heavy metals such as aluminium (Al), lead $(\mathrm{Pb})$, cadmium $(\mathrm{Cd})$, gold $(\mathrm{Au})$, mercury $(\mathrm{Hg})$, and silver $(\mathrm{Ag})$ do not have any biological role and are toxic to living organisms [30]-[33]. Toxicity of heavy metals depends on the bioavailability of heavy metal and the absorbed dose [34].

Table $\mathrm{V}$ shows the trace elements concentrations by industry type. It should be noted that sulphide, chloride, and fluoride were detected in small quantities in all wastewaters. No major deviations were observed except the presence of chromium, copper, and zinc at significant levels in the beverage industry, the presence of mercury in the food industry only in addition to lead.

In terms of biological analysis (Table VI), TC, FC, E. coli, Salmonella, and fungi, were detected in most wastewaters while enterococci, coliphage viruses, and parasites were not detected in any wastewater.

TABLE V: TRACE ELEMENTS OF INDUSTRIAL WASTEWATER (MG/L)

\begin{tabular}{|c|c|c|c|c|c|c|c|c|}
\hline Industry & $\mathrm{Al}$ & As & $\mathrm{Ba}$ & $\mathrm{B}$ & $\mathrm{Cd}$ & $\mathrm{Co}$ & $\mathrm{Cr}$ & $\mathrm{Cu}$ \\
\hline Beverage & $8.2 \pm 1.4$ & $2.9 \pm 0.7$ & $13.8 \pm 3.9$ & $0.0 \pm 0.0$ & $1.9 \pm 0.7$ & $0.5 \pm 0.1$ & $2.6 \pm 0.7$ & $8.1 \pm 1.6$ \\
\hline construction materials & $9.4 \pm 0.8$ & $3.5 \pm 0.4$ & $9.3 \pm 0.7$ & $0.6 \pm 0.2$ & $1.0 \pm 0.2$ & $1.0 \pm 0.2$ & $4.1 \pm 0.6$ & $6.5 \pm 0.7$ \\
\hline Dairy & $12.8 \pm 2.5$ & $3.8 \pm 1.1$ & $9.9 \pm 2.2$ & $0.0 \pm 0.0$ & $0.4 \pm 0.2$ & $0.5 \pm 0.1$ & $2.7 \pm 0.9$ & $6.1 \pm 2.5$ \\
\hline Farms & $5.9 \pm 1.3$ & $2.5 \pm 0.6$ & $8.1 \pm 1.4$ & $0.0 \pm 0.0$ & $0.5 \pm 0.3$ & $1.2 \pm 0.4$ & $1.0 \pm 0.4$ & $7.8 \pm 1.7$ \\
\hline Food & $4.3 \pm 16.3$ & $9.1 \pm 1.0$ & $2.9 \pm 0.5$ & $10.3 \pm 1.0$ & $0.0 \pm 0.0$ & $1.4 \pm 0.5$ & $0.9 \pm 0.2$ & $3.0 \pm 0.54$ \\
\hline Metal forming & $8.2 \pm 1.8$ & $4.5 \pm 1.2$ & $7.2 \pm 1.6$ & $1.9 \pm 0.8$ & $1.3 \pm 0.7$ & $0.6 \pm 0.1$ & $0.9 \pm 0.3$ & $3.7 \pm 0.9$ \\
\hline Paper and packaging & $9.4 \pm 1.2$ & $5.4 \pm 0.9$ & $9.9 \pm 1.2$ & $1.8 \pm 0.7$ & $2.0 \pm 0.4$ & $4.0 \pm 0.7$ & $7.0 \pm 1.1$ & $6.8 \pm 1.0$ \\
\hline Petrochemical & $8.9 \pm 0.9$ & $7.0 \pm 0.9$ & $8.8 \pm 0.8$ & $1.3 \pm 0.5$ & $2.2 \pm 0.5$ & $1.6 \pm 0.4$ & $6.5 \pm 0.9$ & $7.0 \pm 0.9$ \\
\hline Poultry & $11.4 \pm 1.9$ & $5.7 \pm 1.3$ & $9.8 \pm 1.4$ & $0.4 \pm 0.1$ & $1.3 \pm 0.8$ & $0.6 \pm 0.1$ & $3.6 \pm 1.1$ & $10.1 \pm 1.8$ \\
\hline Printing & $10.8 \pm 1.5$ & $8.0 \pm 1.7$ & $13.5 \pm 1.8$ & $0.0 \pm 0.0$ & $1.2 \pm 0.4$ & $2.0 \pm 0.4$ & $6.0 \pm 1.2$ & $15.1 \pm 3.6$ \\
\hline Slaughterhouses & $12.2 \pm 1.8$ & $4.5 \pm 1.1$ & $11.8 \pm 1.7$ & $0.0 \pm 0.0$ & $0.8 \pm 0.4$ & $0.5 \pm 0.1$ & $3.3 \pm 1.1$ & $8.8 \pm 1.5$ \\
\hline Industry & $\mathrm{Fe}$ & $\mathrm{Hg}$ & $\mathrm{Mn}$ & $\mathrm{Ni}$ & $\mathrm{Pb}$ & $\mathrm{Sb}$ & $\mathrm{Zn}$ & $\mathrm{Al}$ \\
\hline Beverage & $0.1 \pm 0.0$ & $0.0 \pm 0.0$ & $7.9 \pm 1.6$ & $5.4 \pm 1.2$ & $0.6 \pm 0.3$ & $0.0 \pm 0.0$ & $7.8 \pm 1.7$ & $8.2 \pm 1.4$ \\
\hline construction materials & $0.1 \pm 0.0$ & $0.0 \pm 0.0$ & $5.5 \pm 0.7$ & $2.6 \pm 0.4$ & $0.7 \pm 0.2$ & $0.0 \pm 0.0$ & $10.2 \pm 1.6$ & $9.4 \pm 0.8$ \\
\hline Dairy & $0.0 \pm 0.0$ & $0.0 \pm 0.0$ & $2.6 \pm 0.8$ & $2.7 \pm 0.6$ & $0.4 \pm 0.2$ & $0.0 \pm 0.0$ & $5.0 \pm 1.6$ & $12.8 \pm 2.5$ \\
\hline Farms & $0.0 \pm 0.0$ & $0.0 \pm 0.0$ & $7.4 \pm 1.4$ & $3.7 \pm 0.7$ & $0.0 \pm 0.0$ & $0.0 \pm 0.0$ & $13.3 \pm 1.9$ & $5.9 \pm 1.3$ \\
\hline Food & $6.1 \pm 0.8$ & $0.4 \pm 0.1$ & $0.0 \pm 0.0$ & $7.3 \pm 0.9$ & $5.8 \pm 0.8$ & $1.4 \pm 0.4$ & $0.0 \pm 0.0$ & $8.7 \pm 1.6$ \\
\hline Metal forming & $0.2 \pm 0.1$ & $0.0 \pm 0.0$ & $5.0 \pm 1.3$ & $3.3 \pm 1.4$ & $3.0 \pm 1.1$ & $0.0 \pm 0.0$ & $5.6 \pm 1.4$ & $8.2 \pm 1.8$ \\
\hline Paper and packaging & $2.1 \pm 0.6$ & $0.0 \pm 0.0$ & $6.6 \pm 1.0$ & $6.2 \pm 1.0$ & $5.2 \pm 1.1$ & $0.0 \pm 0.0$ & $9.3 \pm 1.1$ & $9.4 \pm 1.2$ \\
\hline Petrochemical & $0.6 \pm 0.2$ & $0.0 \pm 0.0$ & $5.7 \pm 0.8$ & $3.9 \pm 0.7$ & $2.2 \pm 0.5$ & $0.0 \pm 0.0$ & $8.5 \pm 1.0$ & $8.9 \pm 0.9$ \\
\hline Poultry & $0.0 \pm 0.0$ & $0.0 \pm 0.0$ & $10.8 \pm 1.8$ & $3.3 \pm 0.9$ & $0.5 \pm 0.2$ & $0.0 \pm 0.0$ & $12.7 \pm 1.7$ & $11.4 \pm 1.9$ \\
\hline Printing & $0.4 \pm 0.2$ & $0.0 \pm 0.0$ & $4.9 \pm 1.0$ & $5.5 \pm 1.3$ & $3.9 \pm 1.1$ & $0.0 \pm 0.0$ & $10.3 \pm 2.1$ & $10.8 \pm 1.5$ \\
\hline Slaughterhouses & $0.1 \pm 0.0$ & $0.0 \pm 0.0$ & $12.6 \pm 1.8$ & $7.0 \pm 1.6$ & $0.2 \pm 0.1$ & $0.0 \pm 0.0$ & $14.4 \pm 1.9$ & $12.2 \pm 1.8$ \\
\hline
\end{tabular}

TABLE VI: AVERAGE BIOLOGICAL PARAMETERS OF INDUSTRIAL WASTEWATER

\begin{tabular}{|c|c|c|c|c|c|c|c|c|}
\hline Industry type & T.C. & F. C. & E. Coli & Enterococci & Salmonella & Fungi & Coliphage & Parasites \\
\hline Beverage & 525970 & 78804 & 7802 & ND & 9113 & 1467 & ND & ND \\
\hline Construction materials & 322304 & 7980 & 1511 & ND & 5859 & 3943 & ND & ND \\
\hline Dairy & 289377 & 36923 & 4882 & ND & 6618 & 1071 & ND & ND \\
\hline Farms & 242976 & 25500 & 6541 & ND & 7377 & 542 & ND & ND \\
\hline Food & 435737 & 29515 & 4032 & ND & 64881 & 5035 & ND & ND \\
\hline Metal forming & 347889 & 7547 & 4114 & ND & 7732 & 1246 & ND & ND \\
\hline Paper and packaging & 437081 & 16910 & 2076 & ND & 47198 & 4333 & ND & ND \\
\hline Petrochemical & 461016 & 10344 & 1881 & ND & 11328 & 1386 & ND & ND \\
\hline Poultry & 427335 & 37983 & 8630 & ND & 93957 & 3667 & ND & ND \\
\hline Printing & 240118 & 16182 & 4476 & ND & 18719 & 4092 & ND & ND \\
\hline Slaughterhouses & 253467 & 27638 & 5292 & ND & 39935 & 7862 & ND & ND \\
\hline
\end{tabular}

\section{B. Industrial Wastewater Toxicity}

Bioassays that employ different test methods can be used to directly characterize the toxicity levels of various industrial chemicals and wastewaters [35]. Previous studies have demonstrated that the dehydrogenase activity (DHA) assay can be used to evaluate biological wastewater treatments and water toxicity as the DHA assay as a bioassay method has high sensitivity, is simple to perform, has a low cost, and allows quantification [36], [37]. The freshwater luminescent bacteria Vibrio qinghaiensis is one of the most widely used organisms in toxicity analyses, has been used to facilitate easy, rapid, and suitable freshwater bioassays, and provides reliable toxicity measurements of chemicals and wastewater [3], [38].

In this study, the toxicity of the industrial wastewater in Kuwait was assayed using Microtox toxicity assay system that has found wide acceptance over the last decade. The test organism (luminescent bacteria, Aliivibriofischeri) is highly sensitive to a broad range of toxicants. The suspension used in the test contains about one million microorganisms which gives high resolution response compared to other bioassays 
because of such a large population.

Toxicity averages for different industrial categories are shown in Fig. 5. It appears that the toxicity of the industrial wastewater is similar with the exception of farm wastewater which has a relative toxicity score higher that other industries. This is attributed to less use of chemicals in farms and therefore their wastewater is mostly less harmful. The most toxic type of industry was found to be metal forming, printing, and dairy which have relative toxicity of $<25 \%$. In the second place came slaughterhouses, petrochemical, poultry and food industries which have slightly higher relative toxicity score. This ranking is an average ranking and, in many cases, individual samples have shown a different ranking.

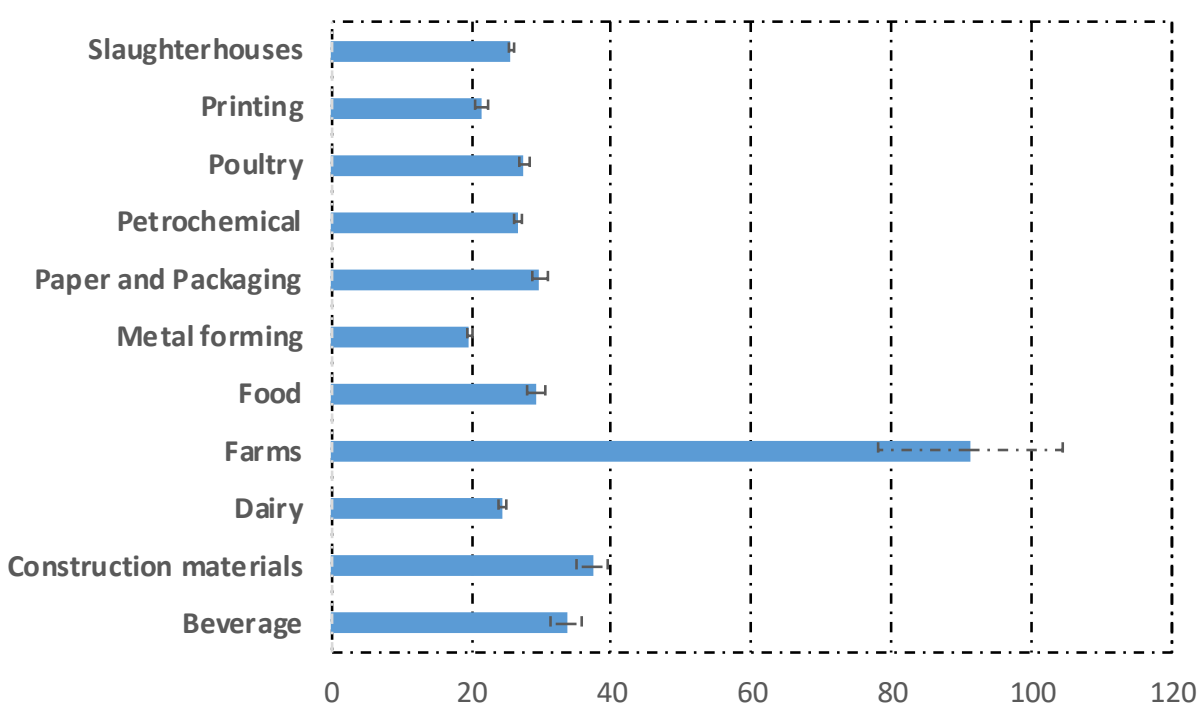

Fig. 5. Average relative toxicity by industry.

Toxicity was classified into five groups based on the effective concentration (EC) values of the toxic material in the sample (Mantis et al. 2005, Katsoyannis and Samara 2007). These five groups are Very Toxic (EC50 :<25\%), Moderately Toxic (EC50: 25-50\%), Toxic (EC50:51-75\%), Slightly Toxic (EC50:75-100\%), and Not Toxic (EC50 :> $100 \%)$. The results are shown in Table VII which indicates that industrial wastewater in Kuwait is mostly very toxic to moderately toxic. Mostly there were minor differences in the toxicity classification between industries as observed in wastewater treatment plant effluents by Ra et al. [39]. Very few samples fell in the slightly toxic to nontoxic which could be contributed to cleaning periods.

TABLE VII: RESULTS OF TOXICITY CLASSIFICATION OF INDUSTRIAL WASTEWATER

\begin{tabular}{|c|c|c|c|c|c|c|}
\hline Industry & $\begin{array}{c}\text { Total number of } \\
\text { samples }\end{array}$ & $<25$ & $25-50$ & $51-75$ & $75-100$ & $>100$ \\
\hline Beverage & 15 & 12 & 1 & 1 & - & 1 \\
\hline construction materials & 55 & 43 & 5 & 1 & - & 6 \\
\hline Dairy & 6 & 6 & - & - & - & - \\
\hline Farms & 12 & 9 & - & - & - & 3 \\
\hline Food & 34 & 31 & 1 & 1 & - & 1 \\
\hline Metal forming & 11 & 11 & - & - & - & - \\
\hline Paper and packaging & 23 & 20 & 1 & 1 & 1 & - \\
\hline Petrochemical & 29 & 26 & 2 & 1 & - & - \\
\hline Poultry & 12 & 10 & 2 & - & - & - \\
\hline Printing & 13 & 13 & - & - & - & - \\
\hline Slaughterhouses & 12 & 11 & 1 & - & - & - \\
\hline
\end{tabular}

Few studies attempted to established correlations to infer wastewater toxicity using conventional water quality parameters [40], [41]. Industrial wastewater generally has a broad mix of different components, which implies that the resulting toxic properties may vary depending on the interaction between each of them. This high variability may be responsible for the poor correlation of some parameters with toxicity values [42]. For example, Boluda et al. [40] noted that in complex samples such as in the case of wastewater, COD cannot provide a good correlation with toxicity.

The difference between BOD and COD may represent the non-biochemically oxidizable organics, total metal presence, PAHs, phenol, and BTEX may be indicative of the reasons behind the toxicity of the different types of wastewater. The difference between the overall industrial wastewater average and the values of the indicators for the corresponding industry type is used to examine this hypothesis (Table VIII).

Although the beverage and metal forming industries do not show up under any categories, it was observed that the beverage industry has the lowest average $\mathrm{pH}(5.7 \pm 0.1)$, while the metal forming industry has the highest temperature $\left(37.7 \pm 2.5^{\circ} \mathrm{C}\right)$. These facts point towards the effect of $\mathrm{pH}$ and temperature on toxicity. Although the source of TPH in the dairy industry is not clear, the dairy industry wastewater is very toxic due to presence of elevated levels of TPH. This is the same in the case of farms wastewater. Mostly, dairy and farms are combined industries in Kuwait. 
TABLE VIII: TOXICITY AND RANKING OF KEY WASTEWATER PARAMETERS

\begin{tabular}{|c|c|c|c|c|c|c|c|c|}
\hline Industry & COD-BOD & TOC & Metals & NH3 & TPH & Phenol & BTEX & Toxicity \\
\hline Beverage & - & - & - & - & - & - & - & $33.6 \pm 4.7$ \\
\hline Construction materials & - & 3 & - & - & 2 & - & - & $37.4 \pm 4.4$ \\
\hline Dairy & - & - & - & - & 3 & - & - & $24.5 \pm 1.1$ \\
\hline Farms & - & - & - & - & 4 & - & - & $91.2 \pm 26.3$ \\
\hline Food & - & - & - & 1 & - & 1 & - & $29.4 \pm 2.7$ \\
\hline Metal forming & - & - & - & - & - & - & - & $19.7 \pm 0.7$ \\
\hline Paper and packaging & 3 & 1 & 3 & - & - & - & - & $29.8 \pm 2.2$ \\
\hline Petrochemical & 2 & 2 & 5 & - & 1 & 2 & 1 & $26.7 \pm 0.9$ \\
\hline Poultry & 1 & - & 4 & 2 & - & - & - & $27.6 \pm 1.3$ \\
\hline Printing & - & - & 1 & - & - & - & - & $21 \pm 1.9$ \\
\hline Slaughterhouses & - & - & 2 & 3 & - & - & - & $25.7 \pm 0.5$ \\
\hline
\end{tabular}

By examining Table VIII, metals in the printing industry are probably the main cause of toxicity, while metals and ammonia are the main contributors to the toxicity in slaughterhouses. Also, poultry wastewater has elevated levels of COD, ammonia, and metals as the major sources of toxicity, the paper and packaging industry are high in COD, TOC, and metals, the food industry has elevated levels of ammonia and phenol, while the construction materials wastewater has elevated levels of TOC and TPH [43]. The petrochemical industry is the only industry at which all parameters are contributing to its toxicity.

\section{CONCLUSIONS}

The survey results indicated that industrial wastewater in Kuwait are highly toxic with the exception of farms wastewater. Among the contributing factors to the toxicity of industrial wastewater are temperature, $\mathrm{pH}$, metals, COD, TOC, NH3, TPH, phenol, and BTEX. This conclusion is important in prioritizing industrial wastewater treatment objectives while targeting toxicity reduction.

\section{CONFLICT OF INTEREST}

The authors declare no conflict of interest.

\section{AUTHOR CONTRIBUTIONS}

Mohd Elmuntasir Ahmed is the main writer of the paper, A. Al-Haddad conducted the research sampling and analysis, and S. Al-Dufaileej was responsible for toxicity testing and reporting; all authors had approved the final version.

\section{REFERENCES}

[1] Butarewicz, E. Wrzaszcz, and S. Rosochacki, "Toxicity of sewage from industrial wastewater tratment plants," Journal of Ecological Engineering, vol. 20, no. 2, pp. 191-199, 2018.

[2] G. Saxena, R. Chandra, and R. N. Bharagava, "Environmental pollution, toxicity profile and treatment approaches for tannery wastewater and its chemical pollutants," Reviews of Environmental Contamination and Toxicology vol. 240. Reviews of Environmental Contamination and Toxicology (Continuation of Residue Reviews), Springer, Cham, pp. 217-247, 2016.

[3] M. Ma, Z. Tong, Z. Wang, and W. Zhu, "Acute toxicity bioassay using the freshwater luminescent bacterium Vibrio-qinghaiensis," Bulletin of Environmental Contamination and Toxicology, vol. 62, pp. 247-253, 1999.

[4] G. Saxena, D. Purchase, and R. N. Bharagava, "Environmental hazards and toxicity profile of organic and inorganic pollutants of tannery wastewater and bioremediation approaches," Bioremediation of Industrial Waste for Environmental Safety, Springer, Singapore. 2020.

[5] D. Alvarez-Bernal, S. M. Contreras-Ramos, N. Trujillo-Tapia, V. Olalde-Portugal, J. T. Frias-Hernandez, and L. Dendooven, "Effects of tanneries wastewater on chemical and biological soil characteristics," Applied Soil Ecology, vol. 33, pp. 269-277, 2006.

[6] R. Oral, S. Meric, E. Nicola, D. Petruzzelli, C. Rocca, and G. Pagano, "Multi-species toxicity evaluation of a chromium-based leather tannery wastewater," Desalination, vol. 211, no. 1-3, pp. 48-57, 2007.

[7] V. Kumar, C. Majumdar, and P.Roy, "Effects of endocrine disrupting chemicals from leather industry effluents on male reproductive system," Journal of Steroid Biochemistry and Molecular Biology, vol. 111, no. 3-5, pp. 208-216, 2008.

[8] V. Tigini, P. Giansanti, A. Mangiavillano, A. Pannocchia, and G. C. Varese, "Evaluation of toxicity, genotoxicity and environmental risk of simulated textile and tannery wastewaters with a battery of biotests," Ecotoxicology and Environmental Safety, vol. 74, no. 4, pp. 866-8673, 2011.

[9] L. Shakir, S. Ejaz, M. Ashraf, Q. N. Aziz, A. A. Ahmad, and I. Iltaf, "Ecotoxicological risks associated with tannery effluent wastewater," Environmental Toxicology and Pharmacology, vol. 34, no. 2, pp. 180-191, 2012.

[10] G. Lofrano, E. Aydin, F. Russo, M. Guida, V. Belgiorno, and S. Meric, "Characterization, fluxes and toxicity of leather tanning bath chemicals in a large tanning district area (IT)," Water Air and Soil Pollution, vol. 8, pp. 529-542, 2008.

[11] G. Saxena and R. N. Bharagava, "Persistent organic pollutants and bacterial communities present during the treatment of tannery wastewater," Environmental Waste Management, CRC Press, Taylor and Francis Group, Boca Raton, FL, 2015.

[12] J. J. Rueda-Márquez, I. Levchuk, M. Manzano, and M. Sillanpää, "Toxicity reduction of industrial and municipal wastewater by advanced oxidation processes (photo-fenton, UVC/H2O2, electro-fenton and galvanic fenton): A review," Catalysts, 2020.

[13] U. N. Rai, S. Dwivedi, R. D. Tripathi, O. P. Shukla, and N. K. Singh, "Algal biomass: An economical method for removal of chromium from tannery effluent," Bulletin of Environmental Contamination and Toxicology, vol. 75, no. 2, pp. 297-303, 2005.

[14] R. K. Sahu, S. Katiyar, J. Tiwari, and G. C. Kisku, "Assessment of drain water receiving effluent from tanneries and its impact on soil and plants with particular emphasis on bioaccumulation of heavy metals," Journal of Environmental Biology, vol. 28, no. 3, pp. 685-690, 2007.

[15] F. Sánchez-Bayo, "From simple toxicological models to prediction of toxic effects in tim.," Ecotoxicology, vol. 18, pp. 343-354, 2009.

[16] T. Verma, P. W. Ramteke, and S. K. Garg, "Quality assessment of treated tannery wastewater with special emphasis on pathogenic $E$. coli detection through serotyping," Environmental Monitoring and Assessment, vol. 145, no. 1-3, pp. 243-249, 2008.

[17] S. R. Tariq and A. Bashir, "Speciative distribution and bioavailability of metals in agricultural soils receiving industrial wastewater," Environmental Monitoring and Assessment, vol. 184, pp. 4609-4622, 2012.

[18] D. Rameshraja and S. Suresh, "Treatment of tannery wastewater by various oxidation and combined processes," International Journal of Environmental Research, vol. 5, no. 2, pp. 349-360, 2011.

[19] R. N. Bharagava, S. Yadav, and R. Chandra, "Antibiotic and heavy metal resistance properties of bacteria isolated from the aeration lagoons of common effluent treatment plant (CETP) of tannery industries (Unnao, India)," Indian Journal of Biotechnology, vol. 13, no. 4, pp. 514-519, 2014.

[20] D. Chavan, D. Thacker, and D. Tarar, "Toxicity Evaluation of Pesticide Industry Wastewater through Fish Bioassay," IRA-International Journal of Applied Sciences, vol. 3, no. 3, pp. 331-339, 2016.

[21] G. Yilmaz, Y. Kaya, I. Vergili et al., "Characterization and toxicity of hospital wastewaters in Turkey," Environmental Monitoring and Assessment, https://doi: 10.1007/s10661-016-5732-2, 2017. 
[22] D. T. Sponza, "Necessity of toxicity assessment in turkish industrial discharges (examples from metal and textile industry effluents)," Environmental Monitoring and Assessment, vol. 73, pp. 41-66, 2002.

[23] D. Barceló, B. Žonja, and A. Ginebreda, "Toxicity tests in wastewater and drinking water treatment processes: A complementary assessment tool to be on your radar," Journal of Environmental Chemical Engineering, 2020.

[24] PHA, Standard Method for the Examination of Water and Wastewater; American Public Health Association, Washington, D.C., USA. 2017.

[25] M. J. Ruiz, L. Lopez-Jaramillo, M. J. Redondo, and G. Font, "Toxicity assessment of pesticides using the Microtox test: application to environmental samples," Bulletin of Environmental Contamination and Toxicology, vol. 59, pp. 619-625, 1997.

[26] W. E. Coleman and A. A. Qureshi, "Microtox and spirillum polutants tests for assessing toxicity of environmental samples," Bulletin of Environmental Contamination and Toxicology, vol.35, pp. 443-451, 1985.

[27] T. Saeed, M. Al-mutairi, L. N. Ali, T. Al-obaid, and M. U. Beg, "The effect of temperature on the composition and relative toxicity of the water-soluble fraction of Kuwait crude oil (export) in the seawater," International Journal of Environmental Analytical Chemistry, vol. 72, no. 4, pp. 275-287, 1998.

[28] K. Choi and P. G. Meier, "Toxicity evaluation of metal plating wastewater employing the Microtox ${ }^{\circledR}$ assay: A comparison with cladocerans and fish," Environmental Toxicology, vol. 16, pp. 136-141, 2001.

[29] U.S. Environmental Protection Agency, Methods for Measuring the Acute Toxicity of Effluents and Receiving Waters to Freshwater and Marine Organisms, $4^{\text {th }}$ ed., EPA 600_4-90_027F: Washington, DC. 1993.

[30] S. Siddiquee, K. Rovina, and S. A. Azad, "Heavy metal contaminants removal from wastewater using the potential filamentous fungi biomass: a review," Journal of Microbial and Biochemical Technology, vol. 7, no. 6, pp. $384-393,2015$.

[31] D. Lakherwal, "Adsorption of heavy metals: A review," International Journal of Environmental Research Development, vol. 4, pp. 41-48, 2014.

[32] R. Turpeinen, T. Kairesalo, and M. Haggblom, "Microbial activity community structure in arsenic, chromium and copper contaminated soils," Journal of Environmental Microbiology, vol. 35, no. 6, pp. 998-1002, 2002.

[33] R. M. Machado, L. O. Monteggia, A. Arenzon et al., "Assessment of the toxicity of wastewater from the metalworking industry treated using a conventional physico-chemical process," Environmental Monitoring and Assessment, 2016.

[34] L. D. Rasmussen, S. J. Sørensen, R. R. Turner, and T. Barkay, "Application of a mer-lux biosensor for estimating bioavailable mercury in soil," Soil Biology and Biochemistry, vol. 32, no. 5, pp. 639-646, 2000

[35] K. Ma., Z. Qin, Z. Zhao, C. Zhao, and S. Liang, "Toxicity evaluation of wastewater collected at different treatment stages from a pharmaceutical industrial park wastewater treatment plant," Chemosphere, vol. 158, pp. 163-170, 2016.

[36] M. Barajas-Aceves., J. Corona-Hern, and R. Rodríguez-Vazquez, "Chromium fractionation in semi-arid soils amended with chromium and tannery sludge," Journal of Hazardous Materials, vol. 146, pp. 91-97, 2007.

[37] R. Zhang, R. Jin, G. Liu, J. Zhou, and C. L. Li, "Study on nitrogen removal performance of sequencing batch reactor enhanced by low intensity ultrasound," Bioresource and Technology, vol. 102, pp. 5717-5721, 2011.

[38] Z. Ye, Q. Zhao, M. Zhang, and Y. Gao, "Acute toxicity evaluation of explosive wastewater by bacterial bioluminescence assays using a freshwater luminescent bacterium, Vibrio qinghaiensis," Journal of Hazardous Materials, vol. 186, pp. 1351-1354, 2011.

[39] J. S. Ra, H. K. Kim, N. I. Chang et al., "Whole effluent toxicity (WET) tests on wastewater treatment plants with daphnia magna and selenastrum capricornutum," Environmental Monitoring and Assessment, vol. 129, pp. 107-113, 2007.

[40] R. Boluda, J. F. Quintanilla, J. A. Bonilla, E. Sáez, and M. Gamón, "Application of the Microtox ${ }^{\circledR}$ test and pollution indices to the study of water toxicity in the Albufera Natural Park (Valencia, Spain)," Chemosphere, vol. 46, no. 2, pp. 355-369, 2002.

[41] S. K. Golfinopoulos and G. B. Arhonditsis, "Multiple regression models: A methodology for evaluating trihalomethane concentrations in drinking water from raw water characteristics," Chemosphere, vol 47, no. 9, pp. 1007-1018, 2002.

[42] D. C. Rodríguez, O. Ramírez-Henao, and G. Peñuela-Mesa, "Assessment of toxicity in industrial wastewater treated by biological processes using luminescent bacteria," Actualidades Biológicas, vol. 38, pp. 211-216, 2016.

[43] A. Al-haddad, M. E. Ahmed, H. Abdullah, and R. Al-Yaseen, "Anomalies in industrial wastewater quality data in Kuwait," Data in Brief, vol. 35, 2021.

Copyright (C) 2022 by the authors. This is an open access article distributed under the Creative Commons Attribution License which permits unrestricted use, distribution, and reproduction in any medium, provided the original work is properly cited (CC BY 4.0).

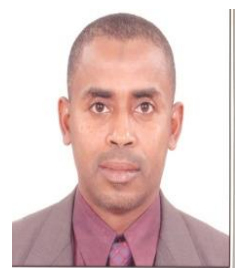

Mohd Elmuntasir Ebrahim Ahmed was born in Khartoum, Sudan and received B.Sc. (Honors) in civil engineering from the University of Khartoum, Khartoum, Sudan in 1992, M.Ss. in civil engineering (environmental engineering) from Bradley University, Peoria, IL, USA in 1996, and Ph.D. in environmental engineering from Illinois Institute of Technology (IIT), Chicago, IL, USA in 2000. Currently, he is a research scientist at the Wastewater Treatment and Reclamation (WTRT) Program at Kuwait Institute for Scientific Research (KISR) in Kuwait.

His experience includes: International staff with UN, Regional staff the Nile Transboundary Environmental Action Program, Associate Professor of at the University of Khartoum, Environmental Engineering Consultant with the University of Khartoum Consultancy Corporation, and Graduate Research Assistant at Illinois Institute of Technology. Research areas include: Low energy ion-exchange membrane processes, Adsorption processes, Hybrid biological processes for oil produced water treatment, Decision theory application for wastewater treatment plant operation, and environmental assessment.

Dr Ahmed is a fellow of the Sudanese Engineering Society. He was awarded Who's Who Among American Colleges and Universities (1997) and won many research grants. He has over 40 publications in international scientific journals and conferences.

Adel Al-Haddad is a research scientist and program manager of the wastewater treatment and reclamation technologies program at the Water Research Center (WRC) of Kuwait Institute for Scientific Research (KISR) Dr Adel Obtained his PhD in environmental engineering from Glasgow University.

Suad Al-Dhufaileej is a research associate at the Environment and Life Science Research Center (ELSRC) of Kuwait Institute for Scientific Research (KISR). 